\title{
PEMANFAATAN LIMBAH POPOK BAYI (DIAPERS) SEBAGAI MEDIA TANAM
}

\author{
Fajar Dwi Prasetyo ${ }^{1)}$, Rita Dewi Triastianti ${ }^{2)}$ Endah Ayuningtyas ${ }^{3)}$ \\ ${ }^{1)}$ Mahasiswa S1 Teknik Lingkungan Institut Teknologi Yogyakarta, ${ }^{23)}$ Dosen S1 Teknik Lingkungan Institut \\ Teknologi Yogyakarta \\ email: endaha25@ity.ac.id ${ }^{3)}$
}

\begin{abstract}
ABSTRAK
Tingginya pemakaian popok bayi tanpa diimbangi dengan sistem pengelolaan atau pemanfaatan akan menjadi permasalahan pada lingkungan. Popok bayi memiliki kandungan hidrogel yang dapat menyerap dan mempertahankan air. Tujuan penelitian ini adalah untuk mengetahui pengaruh hidrogel yang telah difermentasi dengan EM4 selama 7 hari terhadap peningkatan kandungan Nitrogen $(\mathrm{N})$, Fosfor $(\mathrm{P})$, kalium (K), dan kadar lengas (kandungan air).

Penelitian menggunakan variasi tanah $1 \mathrm{~kg}$ : hidrogel $3 \mathrm{~kg}$, tanah $2 \mathrm{~kg}$ : hidrogel

$2 \mathrm{~kg}$, dan tanah $3 \mathrm{~kg}$ : hidrogel $1 \mathrm{~kg}$. Pengukuran N, P, dan K dilakukan pada hari ke0 dan pada hari ke-14. Hasil penelitian menunjukkan kualitas media yang paling baik pada hari ke-14 adalah $1 \mathrm{~kg}$ : hidrogel $3 \mathrm{~kg}$ dengan rerata $\mathrm{N}$ sebesar $0,61 \%$, P sebesar $0,54 \%$, K sebesar $0,63 \%$ dan kadar lengas sebesar 5,43\%. Data disajikan dalam bentuk tabel dan grafik dengan menggunakan analisis data ANOVA satu arah dan uji $\mathrm{T}$ Test dengan membandingkan perlakuan pada hari ke-0 dan ke-14.

Hasil dari perhitungan ANOVA N, P, K, dan kadar lengas menunjukkan hasil yang tidak signifikan pada tiap variasi media tanam. Hasil dari perhitungan T Test N, P, dan K menunjukkan bahwa pada variasi komposisi $1 \mathrm{~kg}$ : hidrogel $3 \mathrm{~kg}$ dan tanah $2 \mathrm{~kg}$ : hidrogel $2 \mathrm{~kg}$ memberikan pengaruh yang signifikan terhadap peningkatan kandungan $\mathrm{N}$, $\mathrm{P}$, dan $\mathrm{K}$ dan pada variasi komposisi tanah $3 \mathrm{~kg}$ : hidrogel $1 \mathrm{~kg}$ tidak memberikan pengaruh yang signifikan terhadap peningkatan kandungan N, P, dan K. Hasil dari perhitungan T Test kadar lengas media pada semua variasi media tanam memberikan pengaruh yang signifikan.
\end{abstract}

Kata kunci: Hidrogel, EM4, Nitrogen, Fosfor, Kalium, Kadar Lengas

\section{UTILIZATION OF BABY DIAPERS AS A PLANT MEDIA}

\begin{abstract}
The high use of baby diapers without offset by a management or utilization system will be a problem in the environment. Baby diapers contain hydrogels that can absorb and retain water. The purpose of this study was to determine the effect of hydrogel that has been fermented with EM4 for 7 days to increase the content of Nitrogen $(N)$, Phosphorus (P), potassium (K), and moisture content (water content).

The study used $1 \mathrm{~kg}$ soil variation: $3 \mathrm{~kg}$ hydrogel, $2 \mathrm{~kg}$ soil: $2 \mathrm{~kg}$ hydrogel, and $3 \mathrm{~kg}$ soil: $1 \mathrm{~kg}$ hydrogel. Measurements of $N, P$, and $K$ were carried out on the 0 th day and on the 14th day. The results showed that the best media quality on the 14th day was $1 \mathrm{~kg}: 3 \mathrm{~kg}$ hydrogel with an average $\mathrm{N}$ of $0.61 \%, P$ of $0.54 \%, \mathrm{~K}$ of $0.63 \%$ and moisture content of $5.43 \%$. Data is presented in tabular and graphical form using oneway ANOVA data analysis and T-Test by comparing treatment on days 0 and 14.

The results of ANOVA N, P, K, and moisture content calculations showed insignificant results on each variation of the planting media. The results of the calculation of $T$ Test $N, P$, and $K$ show that the variation in composition of $1 \mathrm{~kg}: 3 \mathrm{~kg}$ hydrogel and $2 \mathrm{~kg}$ soil: $2 \mathrm{~kg}$ hydrogel gives a significant effect on increasing the content of $N, P$, and $K$ and on variations in soil composition $3 \mathrm{~kg}$ : hydrogel $1 \mathrm{~kg}$ did not have a significant effect on increasing the content of $N, P$, and $K$. The results of the calculation of $T$ Test moisture content of the media on all variations of the planting media gave a significant effect.

Keywords: Hydrogel, EM4, Nitrogen, Phosphorus, Potassium, Moisture Content
\end{abstract}

\section{PENDAHULUAN}

Popok bayi (diapers) merupakan kebutuhan yang akan terus menerus meningkat sesuai dengan bertambahnya angka kelahiran bayi. Tingginya pemakaian popok bayi tanpa diimbangi dengan sistem pengelolaan atau pemanfaatan limbah tersebut makan akan menjadi permasalahan di bidang lingkungan, karena waktu yang digunakan untuk mengurai limbah popok bayi pun sangat lama yaitu 250-500 tahun agar terurai sempurna.

Popok bayi memiliki kandungan hidrogel yaitu gel yang dapat menyerap air dan mempertahankan air. Jenis hidrogel yang paling umum digunakan adalah sodium polyacrylate (yang dikenal sebagai "super absorbent polymer" atau SAP dalam industri popok). Bahan ini juga digunakan untuk tanaman untuk mempertahankan air di dalam tanah. Polyacrylate di bawah tekanan 
dapat menahan sejumlah cairan yang sebanyak tiga puluh kali beratnya. Hal ini berkorelasi dengan kompresi (tekanan) yang terjadi saat bayi akan duduk atau berbaring pada popok. Polyacrylate memungkinkan produsen untuk mengurangi berat dan ketebalan popok sebesar 50 persen dan meningkatkan daya serapnya. (Anwar, 2017).

Limbah popok bayi digunakan sebagai media pertumbuhan tanaman karena memiliki keunggulan yang dibutuhkan oleh tanaman. Selain memiliki kandungan hidrogel yang berfungsi untuk mempertahankan air, limbah popok bayi juga memiliki keunggulan yaitu memiliki urine didalamnya. Urine manusia mengandung tiga unsur hara makro yaitu Nitrogen, Fosfor dan Kalium. Diantara semua unsur hara, yang mendominasi adalah nitrogen. (Elisa Esterelita, 2018). Maka dari itu kandungan urine pada limbah popok bayi ini bisa juga digunakan sebagai media tanam setelah dilakukan fermentasi dengan menggunakan EM4 untuk mengurai senyawa organiknya. EM4 mengandung mikroorganisme fermentasi dan sintetik yang terdiri dari bakteri Asam Laktat (Lactobacillus $S p$ ), Bakteri Fotosentetik (Rhodopseudomonas Sp), Actinomycetes Sp, Streptomyces $S P$ dan Yeast (ragi) dan Jamur pengurai selulosa.

Penelitian ini bermaksud melihat pengaruh penambahan hidrogel terhadap peningkatan kadar Nitrogen, Fosfor, Kalium, dan kadar lengas pada media tanam yang telah dicampur dengan menggunakan hidrogel.

\section{BAHAN DAN METODE}

Bahan yang digunakan dalam pembuatan media tanam ini berupa tanah humus dan juga hidrogel dari limbah popok bayi yang mengandung urine. Alat dan bahan lain yang mendukung adalah Persiapan Alat : Ember, Polibag, Timbangan, Pengaduk, Masker, dan Sarung Tangan. Persiapan bahan : Limbah Popok Bayi (diapers), Tanah Humus, EM4, dan Air.

\section{Tahap Perisiapan Diapers}

Limbah diapers yang digunakan adalah limbah yang mengandung urine. Limbah diapers digunting pada bagian luarnya untuk mengambil hidrogel di dalamnya. Gel inilah yang akan digunakan sebagai media tanam. Hidrogel yang telah didapatkan kemudian fermentasi dengan menggunakan EM4 selama 7 hari. Hal ini bertujuan untuk mengurai urine yang terkandung dalam hidrogel. Fermentasi dilakukan dengan variasi : Hidrogel $1 \mathrm{~kg}+100 \mathrm{ml}$ EM4 + 1 lt Air ;Hidrogel $2 \mathrm{~kg}+100 \mathrm{ml} \mathrm{EM} 4+1$ lt Air; Hidrogel $3 \mathrm{~kg}+100 \mathrm{ml}$ EM4 + 1 lt Air.

\section{Tahap Persiapam Tanah}

Tanah yang digunakan adalah tanah humus. Jumlah percobaan adalah 9 buah polibag. Pada setiap polibag diisi dengan hidrogel dan tanah humus sesuai dengan variasi yang telah ditentukan.

\section{Tahap Pencampuran}

Tanah dan hidrogel dicampur sesuai dengan variasi yang telah ditentukan sampai homogen, hasil campuran tersebut kemudian dimasukkan dalam polibag dan media tanam tersebut didiamkan selama 14 hari tanpa dilakukan penyiraman.

\section{Analisa Media Tanam}

Analisis pertama dilakukan pada awal percobaan yaitu sebelum pencampuran antara tanah dan hidrogel, analisis ini meliputi unsur hara makro N, P, dan K pada masing-masing media serta kadar lengas tanah. Analisis kedua dilakukan pada hari ke-0 setelah pencampuran antara tanah dan diapers sesuai dengan komposisi yang telah ditentukan, analisis ini meliputi unsur hara makro N, P, dan $\mathrm{K}$ serta kadar lengas media dari masing-masing komposisi.

Analisis ketiga dilakukan pada hari ke-14 setelah campuran media tanah dan diapers didiamkan selama 14 hari tanpa dilakukan penyiraman, analisis ini meliputi unsur hara makro N, P, dan $\mathrm{K}$ dari masing-masing komposisi serta kadar lengas media dari masing-masing komposisi.

\section{Uji Kandungan Nitrogen total}

$\mathrm{N}$-organik dan $\mathrm{N}^{-\mathrm{NH}_{4}}$ yang terdapat dalam contoh didestruksi dengan asam sulfat dan selenium mixture membentuk amonium sulfat, didestilasi dengan penambahan basa berlebih dan 
akhirnya destilat dititrasi. Nitrogen dalam bentuk nitrat diekstraksi dengan air, direduksi dengan devarda alloy, didestilasi dan ahirnya dititrasi. (Page, 1982).

Pereaksi :

a. $\mathrm{H}_{4} \mathrm{SO}_{4}$ pa. $98 \%$

b. Larutan baku $\mathrm{H}_{4} \mathrm{SO}_{4} 0,05 \mathrm{~N}$

c. Asam borat $1 \%$

d. Indikator conway

e. Selenium mixture

f. $\mathrm{NaOH} 40 \%$

\section{Uji Kandungan Fosfor dan Kalium Total}

Contoh dioksidasi basah dengan $\mathrm{HNO}_{3}$ dan $\quad \mathrm{HClO}_{4}$. Ekstrak yang diperoleh digunakan untuk mengukur unsur Fosfor secara spektrophotometri dan $\mathrm{K}$ diukur dengan flamefotometer atau spektrometer serapan atom. (Horwitz, 2000).

\section{Pereaksi :}

a. $\mathrm{HNO}_{3}$ pa $65 \%$

b. $\mathrm{HClO}_{4}$ pa $70 \%$

c. Larutan standar induk Kalium $1.000 \mathrm{ppm}$ dalam air bebas ion.

d. Larutan standar induk 500 ppm $\mathrm{PO}_{4}, 500 \mathrm{ppm} \mathrm{S}$ dan $100 \mathrm{ppm}$ B dalam air bebas ion.

e. Larutan $\mathrm{LaCl}_{3} 25.000 \mathrm{ppm}$ ( $67 \mathrm{~g} \mathrm{LaCl}_{3}+15 \mathrm{ml} \mathrm{HCl} 25 \%$ dalam $1.000 \mathrm{ml}$ air bebas ion.

f. Deret standar campuran I mengandung Kalium dalam ekstrak yang sama dengan ekstrak contoh dengan kepekatan sebaai berikut: $0 ; 2 ; 4 ; 8 ; 12 ; 16$; dan 20 ppm Kalium.

g. Deret standar campuran II mengandung: P dengan ekstrak contoh dengan kepekatan sebagai berikut: $0 ; 1 ; 2 ; 4 ; 6 ; 8$; dan 10 ppm $\mathrm{PO}_{4}$.

h. Pereaksi pembangkit pewarna penetapan fosfat: Pereaksi pekat; $12 \mathrm{~g}$ amonium heptamolibdat + $0,275 \mathrm{~g}$ Kalium antimoniltartat $+140 \mathrm{ml} \mathrm{H}_{4} \mathrm{SO}_{4}$ dalam $1.000 \mathrm{ml}$ air bebas ion. Pereaksi encer (dibuat ketika akan digunakan, tidak dapat disimpan); 0,53 g asam askorbat $+50 \mathrm{ml}$ pereaksi pekat dijadikan $500 \mathrm{ml}$ dengan air bebas ion.

\section{Uji Kadar Lengas}

Uji kadar lengas dilakukan dengan memanaskan sampel dalam oven dengan temperatur 105

${ }^{0} \mathrm{C}$ selama 1 jam kemudian ditimbang beratnya.

Perhitungan :

Kadar Lengas $(\%)=(\mathrm{b}-\mathrm{c}$ gr $) /(\mathrm{c}-\mathrm{a}$ gr $) \times 100$

Keterangan :

$\mathrm{a}=$ Berat botol kosong beserta tutupnya (gram)

$\mathrm{b}=$ Berat botol berisi tanah (gram)

$\mathrm{c}=$ Berat botol setelah dipanaskan $($ gram $)$

\section{Analisa Data}

Dari hasil analisis parameter uji dan pengamatan penelitian, maka dilakukan pengolahan data uji statistik dengan menggunakan uji Analysis Of Varian (ANOVA) satu arah untuk mengukur pengaruh variabel serta mendapatkan kesimpulan apakah terdapat perbedaan secara signifikan antara kelompok data dengan perlakuan yang diujikan dan dilanjutkan dengan uji Least Significance Different (LSD). Kemudian dilakukan uji T Test untuk mengukur hubungan antara komposisi pada hari ke-0 dan pada hari ke14. 


\section{HASIL DAN PEMBAHASAN}

Hasil pemeriksaaan laboratorium untuk analisis awal yaitu kandungan $\mathrm{N}, \mathrm{P}$, dan $\mathrm{K}$ pada hidrogel yang telah difermentasi dengan larutan EM4 selama 7 hari dan kandungan N, P, dan K tanah disajikan pada tabel berikut :

Tabel 1. Hasil Uji Awal Kandungan N, P, dan K Pada Tanah dan Hidrogel

\begin{tabular}{ccccc}
\hline \multirow{2}{*}{ Sampel } & \multicolumn{2}{c}{ Nitrogen } & Fosfor & Kalium \\
\cline { 2 - 5 } Hidrogel & Ulangan & 0,07 & 0,04 & 0,06 \\
\cline { 2 - 5 } & 1 & 0,08 & 0,06 & 0,07 \\
\hline \multirow{2}{*}{ Tanah } & 2 & 0,40 & 0,29 & 0,38 \\
& 1 & 0,42 & 0,28 & 0,36 \\
\hline
\end{tabular}

(Sumber : Data Primer 2020)

Dari hasil analisis awal di atas menunjukkan bahwa kandungan $\mathrm{N}$, $\mathrm{P}$, dan $\mathrm{K}$ pada hidrogel memiliki kandungan yang sangat kecil hal ini dikarenakan makan dan minuman yang dikunsumsi oleh balita masih terbatas sehingga perlu ditambahkan dosis pupuk NPK majemuk atau pemberian pupuk urea untuk meningkatkan kandungan $\mathrm{N}$, pupuk TSP/Sp-36 untuk meningkatkan kandungan $\mathrm{P}$, pupuk kalium klorida $(\mathrm{KCl})$ untuk meningkatkan kandungan $\mathrm{K}$. Adapun standar minimum kandungan $\mathrm{N}, \mathrm{P}$ dan $\mathrm{K}$ yang dibutuhkan oleh tanaman adalah $\mathrm{N}: 0,40 \%, \mathrm{P}: 0,10 \%$, dan $\mathrm{K}: 0,20 \%$.

\section{Kandungan Nitrogen (N)}

Tabel 2. Hasil Uji Kandungan Nitrogen pada hari ke-0 dan ke-14

\begin{tabular}{ccccc}
\hline \multirow{2}{*}{ Hari/Ulangan } & \multicolumn{3}{c}{ Komposisi Media (kg) } \\
\cline { 3 - 5 } & & T1D3 & T2D2 & T3D1 \\
\cline { 3 - 5 } & & \multicolumn{3}{c}{} \\
\hline $\mathrm{H}-0$ & 1 & 0,53 & 0,48 & 0,43 \\
& 2 & 0,52 & 0,47 & 0,42 \\
& 3 & 0,50 & 0,48 & 0,42 \\
\hline & Rerata & $\mathbf{0 , 5 2}$ & $\mathbf{0 , 4 8}$ & $\mathbf{0 , 4 2}$ \\
\hline $\mathrm{H}-$ & 1 & 0,62 & 0,50 & 0,46 \\
14 & 2 & 0,60 & 0,51 & 0,44 \\
& 3 & 0,62 & 0,52 & 0,47 \\
& & & \\
\hline & Rerata & $\mathbf{0 , 6 1}$ & $\mathbf{0 , 5 1}$ & $\mathbf{0 , 4 6}$
\end{tabular}

(Sumber : Data Primer 2020)

Berdasakan hasil uji statistik ANOVA terlampir bahwa pengaruh variasi media tanam terhadap kadar Nitrogen memberikan pengaruh yang tidak signifikan. Hal ini berdasarkan pada perhitungan yang menunjukkan hasil dimana F Hitung $(4,44)>F$ Tabel $(9,55)$ dengan $\alpha 5 \%$.

Untuk lebih jelasnya kandungan Nitrogen pada hari ke-0 dan pada hari ke-14 tiap variasi media tanam dapat ditampilkan dalam gambar grafik 1 berikut : 


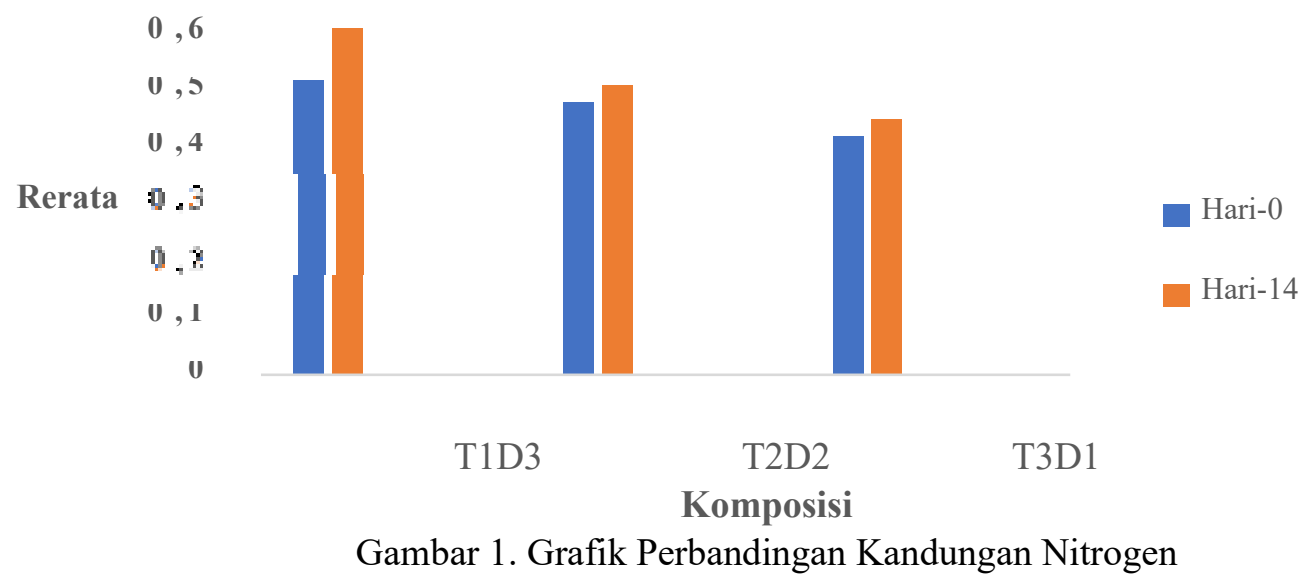

Berdasarkan hasil uji T Test pada tiap variasi untuk memperoleh hubungan antara tiap variasi pada hari ke-0 dan hari ke-14 terhadap peningkatan Nitrogen diperoleh hasil bahwa pada variasi T1D3 dan T2D2 memberikan pengaruh yang signifikan terhadap peningkatan kadar Nitrogen sedangkan pada variasi T3D1 tidak memberikan pengaruh yang signifikan terhadap peningkatan kadar Nitrogen.

Peningkatan kadar Nitrogen terjadi akibat adanya penguraian protein menjadi asam amino dengan bantuan kegiatan mikroorganisme heterotrofik (organisme yang membutuhkan senyawa organik), seperti bakteri, fungi dan actinomycetes. Asam amino kemudian mengalami amonifikasi (proses yang memecah protein, asam amino, dan senyawa yang mengandung nitrogen) menghasilkan amonium. Amonium kemudian dioksidasi oleh bakteri nitromonas menjadi nitrit $\left(\mathrm{NO}_{2}{ }^{-}\right)$dan nitrit dioksidasi oleh bakteri nitrobacter menjadi nitrat $\left(\mathrm{No}_{3}{ }^{-}\right)$. (Alexander, 1977).

\section{Kandungan Fosfor}

Tabel 3. Hasil Uji Kandungan Fosfor pada hari ke-0 dan ke-14

\begin{tabular}{ccccc}
\hline \multirow{2}{*}{ Hari/Ulangan } & \multicolumn{3}{c}{ Komposisi Media $(\mathrm{kg})$} \\
\cline { 3 - 5 } & & T1D3 & T2D2 & T3D1 \\
\cline { 2 - 5 } & 1 & 0,41 & $\mathbf{\%}$ & 0,32 \\
$\mathrm{H}-0$ & 0,43 & 0,37 & 0,33 \\
& 2 & 0,42 & 0,39 & 0,30 \\
\hline $\mathrm{H}-14$ & Rerata & $\mathbf{0 , 4 2}$ & 0,36 & $\mathbf{0 , 3 2}$ \\
& 1 & 0,53 & $\mathbf{0 , 3 7}$ & 0,33 \\
& 2 & 0,55 & 0,46 & 0,30 \\
3 & 0,54 & 0,48 & 0,31 \\
\hline & Rerata & $\mathbf{0 , 5 4}$ & 0,45 & $\mathbf{0 , 3 1}$
\end{tabular}

(Sumber : Data Primer 2020)

Berdasakan hasil uji statistik ANOVA terlampir bahwa pengaruh variasi media tanam terhadap kandungan Fosfor memberikan pengaruh yang tidak signifikan. Hal ini berdasarkan pada perhitungan yang menunjukkan hasil $\mathrm{F}$. Hitung $(3,67)>\mathrm{F}$ Tabel $(9,55)$ dengan $\alpha 5 \%$. Untuk lebih jelasnya kandungan Fosfor pada hari ke-0 dan pada hari ke-14 tiap komposisi media tanam dapat ditampilkan dalam gambar grafik 2 berikut : 


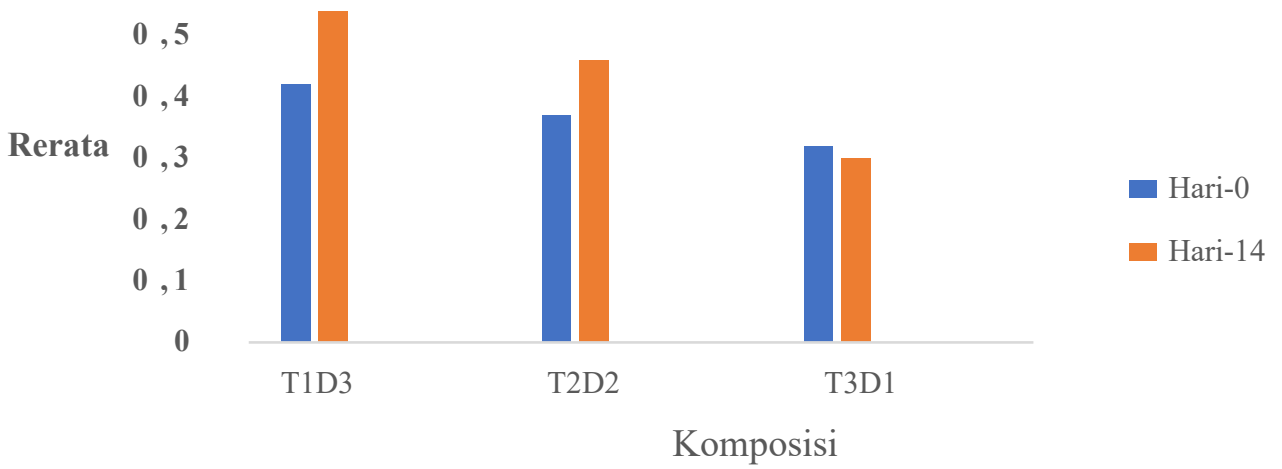

Gambar 2. Grafik Perbandingan Kandungan Fosfor

Berdasarkan hasil uji $\mathrm{T}$ Test pada tiap variasi untuk memperoleh hubungan antara variasi pada hari ke-0 dan hari ke-14 terhadap peningkatan Fosfor diperoleh hasil bahwa pada variasi T1D3 dan T2D2 memberikan pengaruh yang signifikan terhadap peningkatan kadar Fosfor sedangkan pada komposisi T3D1 tidak memberikan pengaruh yang signifikan terhadap peningkatan kandungan Fosfor dan kandungan fosfor mengalami penurunan pada hari ke-14. Peningkatan kadar Fosfor terjadi akibat dari mikroba pelarut fosfat yang mampu melarutkan $\mathrm{Ca}$ fosfat. Spesies dari Pseudomonas, Bacillus, Flavobacterium, Mycobacterium, Micrococcus, Penicillium, Sclerotium, Aspergillus yang mengubah glukosa menjadi asam laktat, sehingga lingkungan menjadi asam yang mengakibatkan Fosfor akan larut dalam asam organik yang dihasilkan mikroorganisme tersebut.

Asam organik mampu mengubah $\mathrm{Ca}_{3}\left(\mathrm{PO}_{4}\right)_{2}$ (Apatit/mineral fosfat) atau material fosfat tidak terlarut lainnya menjadi Fosfat bervalensi satu $\left(\mathrm{H}_{2} \mathrm{PO}_{4}{ }^{-}\right)$dan bervalesi dua $\left(\mathrm{HPO}_{4}^{-2}\right)$ (Amanillah, 2001). Bakteri ini bekerja sama dengan bakteri fotosintesis dan ragi dalam melakukan penguraian. Penurunan kandungan Fosfor karena unsur hara tersebut masih banyak digunakan untuk pertumbuhan kultur mikrobia sehingga kadar Fosfor menurun dan unsur-unsur yang dibebaskan dalam tanah lebih rendah.

Unsur Fosfor diserap dalam bentuk ion $\mathrm{H}_{2} \mathrm{PO}_{4}{ }^{-}$dan ion $\mathrm{HPO}_{4}{ }^{2-}$. Fosfor merupakan penyusun senyawa transfer energi, sistem informasi genetik, merangasang pertumbuhan bunga dan organ tanaman untuk reproduksi (Gardner et al., 1991). Peranan lain unsur Fosfor adalah pemasakan buah dan biji. Sedangkan kekurangan unsur Fosfor dapat mengakibatkan keadaan perakaran tanaman menjadi sangat kurang dan tidak berkembang serta hasil tanaman yang berupa bunga, buah dan biji menjadi merosot (Rosmarkam \& Yuwono, 2002).

\section{Kandungan Kalium}

Tabel 3. Hasil Uji Kandungan Kalium pada hari ke-0 dan ke-14

\begin{tabular}{ccccc}
\hline \multirow{2}{*}{ Ulangan/Hari } & \multicolumn{3}{c}{ Komposisi Media $(\mathrm{kg})$} \\
\cline { 3 - 5 } & & T1D3 & T2D2 & T3D1 \\
\cline { 2 - 5 } & 1 & 0,52 & $\mathbf{\%}$ & 0,5 \\
$\mathrm{H}-0$ & 0,51 & 0,49 & 0,41 \\
& 3 & & 0,47 & 0,41 \\
& Rerata & $\mathbf{0 , 5 1}$ & 0,46 & 0,43 \\
\hline $\mathrm{H}-14$ & 1 & 0,63 & $\mathbf{0 , 4 7}$ & $\mathbf{0 , 4 2}$ \\
\hline & 2 & 0,63 & 0,54 & 0,39 \\
& 3 & 0,64 & 0,55 & 0,41 \\
\hline & Rerata & $\mathbf{0 , 6 3}$ & 0,53 & 0,42 \\
\hline
\end{tabular}

(Sumber : Data Primer 2020) 
Berdasakan hasil uji statistik ANOVA terlampir bahwa pengaruh variasi media tanam terhadap kandungan Kalium memberikan pengaruh yang tidak signifikan. Hal ini berdasarkan pada perhitungan yang menunjukkan hasil F. Hitung $(3,75)>\mathrm{F}$ Tabel $(9,55)$ dengan $\alpha 5 \%$.

Untuk lebih jelasnya kandungan Kalium pada hari ke-0 dan pada hari ke-14 tiap komposisi media tanam dapat ditampilkan dalam gambar grafik 3 berikut :

\section{Perbandingan Kandungan Kalium}

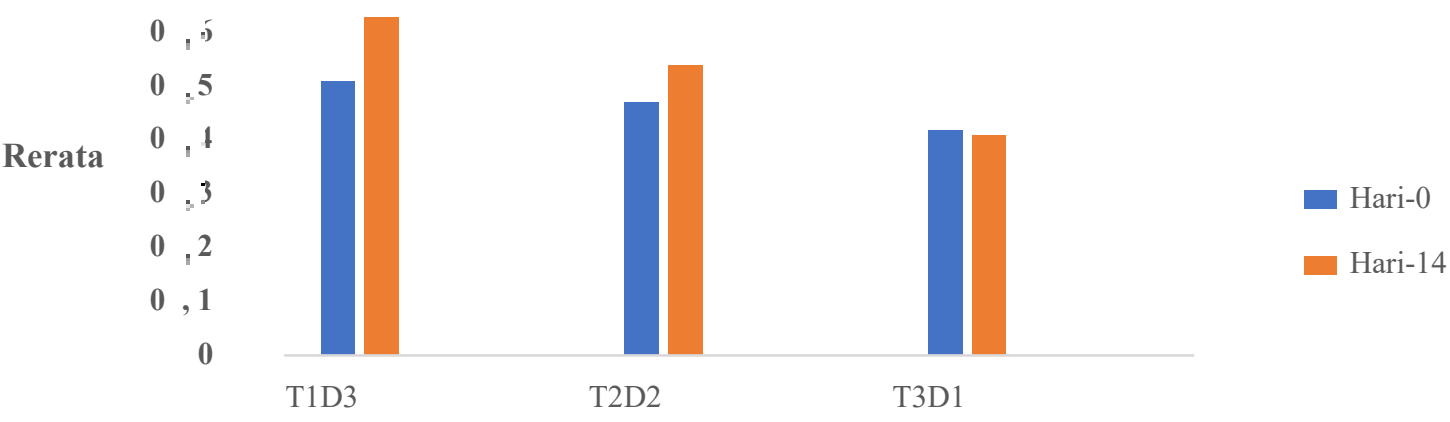

Komposisi

Gambar 3. Grafik Perbandingan Kandungan Kalium

Berdasarkan hasil uji $\mathrm{T}$ Test pada tiap variasi untuk memperoleh hubungan antara variasi pada hari ke-0 dan hari ke-14 terhadap peningkatan Kalium diperoleh hasil bahwa pada variasi T1D3 dan T2D2 memberikan pengaruh yang signifikan terhadap peningkatan kadar Kalium sedangkan pada variasi T3D1 tidak memberikan pengaruh yang signifikan terhadap peningkatan kadar Kalium.Meningkatnya unsur Kalium dikarenakan mikroorganisme yang menggunakan unsur Kalium dalam bahan substrat berfungsi sebagai katalisator, sehingga aktivitas bakteri akan meningkatkan kandungan unsur Kalium pada tanah (Sutedjo, 1996). Selain itu sumber Kalium yang terdapat dalam tanah juga berasal dari pelapukan mineral yang mengandung Kalium. Kalium diserap oleh tanaman dalam bentuk ion $\mathrm{K}^{+}$. Bakteri pelarut Fosfor umumnya juga mampu melarutkan Kalium dalam tanah yang terdapat pada mineral tanah.

\section{Kadar Lengas Media}

Tabel 4. Hasil Uji Kadar Lengas Media

Tanam pada Hari ke-0 dan Ke-14

\begin{tabular}{ccccc}
\hline Ulangan & Kode & Hari -0 & Hari -14 \\
\cline { 4 - 5 } & & & & Kadar Lengas \\
\cline { 4 - 5 } & $\mathbf{1}$ & T1D3 & 6,39 & 5,43 \\
\hline & $\mathbf{2}$ & T1D3 & 5,67 & 4,11 \\
\hline Rerata & $\mathbf{3}$ & T1D3 & 5,70 & 4,68 \\
\hline & $\mathbf{1}$ & $\overline{\boldsymbol{x}}$ & $\mathbf{5 , 9 2}$ & $\mathbf{4 , 7 4}$ \\
\hline & $\mathbf{2}$ & T2D2 & 4,17 & 3,45 \\
\hline & $\mathbf{3}$ & T2D2 & 4,60 & 4,06 \\
\hline Rerata & & T2D2 & 4,33 & 3,70 \\
\hline & $\mathbf{1}$ & $\overline{\boldsymbol{x}}$ & $\mathbf{4 , 3 6}$ & $\mathbf{3 , 7 4}$ \\
\hline & $\mathbf{2}$ & T3D1 & 4,76 & 4,18 \\
\hline & $\mathbf{3}$ & T3D1 & 5,28 & 4,86 \\
\hline Rerata & & T3D1 & 4,68 & 4,02 \\
\hline
\end{tabular}

(Sumber : Data Primer 2020) 
Dari hasil uji kadar lengas media tanam menunjukkan bahwa kadar lengas media tanam dengan perlakuan T1D3 pada hari ke-0 dan ke-14 memiliki kandungan yang lebih besar bila dibandingkan dengan komposisi media tanam lainnya. Sedangkan kadar lengas media terkecil pada komposisi T2D2.

Dari tabel 4. untuk mengetahui secara visual kadar lengas dalam media tanam dapat dilihat pada gambar grafik 4 berikut :

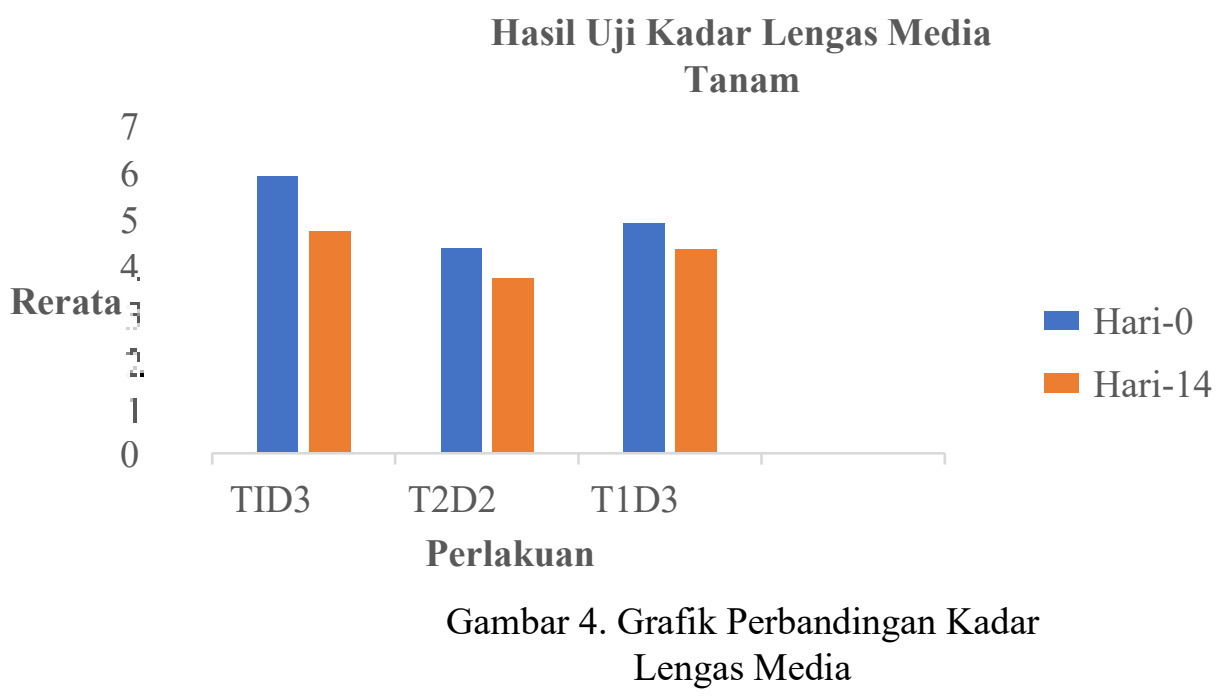

Berdasakan hasil uji statistik ANOVA bahwa pengaruh variasi media tanam terhadap kadar lengas media tanam memberikan pengaruh yang tidak signifikan. Hal ini berdasarkan pada perhitungan yang menunjukkan hasil $\mathrm{F}$. Hitung $(2,33)>\mathrm{F}$ Tabel $(9,55)$ dengan $\alpha 5 \%$.

Berdasarkan hasil uji T Test pada tiap komposisi untuk memperoleh hubungan antara tiap komposisi pada hari ke-0 dan hari ke-14 terhadap kadar lengas media tanam diperoleh hasil bahwa pada komposisi semua komposisi memberikan pengaruh yang signifikan terhadap peningkatan kadar lengas media tanam.

Dari data yang di atas dapat disimpulkan bahwa, variasi media tanam dengan variasi T1D3 memiliki kadar lengas yang tinggi dibandingkan dengan 2 variasi lainnya (T2D2 dan T3D1). Sehingga penggunaan hidrogel dapat meningkatkan kapasitas media menahan air. Akan tetapi penurunan kadar lengas pada hari ke-14 dengan variasi TD1 cenderung lebih rendah dibandingkan dengan 2 variasi lainnya (T1D3 dan T2D2) hal ini dikarenakan karakteristik kedua media yang cenderung lebih basah sehingga terjadinya pelindian yang menyebabkan penurunan kadar lengas media lebih tinggi.

Adapun faktor-faktor lain yang mempengaruhi besar kadar lengas dalam tanah yaitu diantaranya temperatur, iklim, topografi, kandungan bahan organik, dan bahan organik maupun anorganik yang melapisi tanah tersebut. Pada temperatur, pengaruhnya berupa curah hujan yang berselisih dengan penguapan atau evaporasi.

\section{KESIMPULAN}

Variasi media tanam hidrogel dan tanah dapat meningkatkan kandungan $\mathrm{N}$ (Nitrogen), $\mathrm{P}$ (Fosfor), K (Kalium), dan Kadar Lengas media tanam pada hari ke-14. Media tanam dengan variasi komposisi $1 \mathrm{~kg}$ tanah : $3 \mathrm{~kg}$ hidrogel memiliki kadar Nitrogen, Fosfor dan Kalium tertinggi pada hari ke-14. Komposisi media dengan variasi komposisi $1 \mathrm{~kg}$ tanah dan $3 \mathrm{~kg}$ hidrogel memiliki kadar lengas yang lebih tinggi. 


\section{DAFTAR PUSTAKA}

Alexander, M. 1977. Introduction to Soil Microbiology. John Wiley \& Sons, Inc. New York and London

Amanillah, Z, 2001, Pengaruh Konsentrasi EM4 pada Fermentasi Urin Sapi Terhadap Konsentrasi N, P dan K, Skripsi, Fakultas Matematika dan Ilmu Pengetahuan Alam, Universitas Brawijaya, Malang.

Anwar, Thohari. 2017. Info Kimia : Ilmu Kimia Dalam Popok Bayi Sekali Pakai. Tetsedia di :

https://sainskimia.com/info-kimiailmu-kimia-dalam-popok-bayi-sekalipakai/. $\quad(10$ Desember 2019)

Dierolf T, Fairhutst, Mutert E. 2001. Soil Fertility Kit. A Toolkit for Acid Upland Soil Fertility Management in Southeast Asia. Handbook Series. GT2GmbH, Food and Agriculture Organization, P. T. Jasa Katon and Potash \& Phosphate Institute (PPI), Potash \& Phosphate Institute of Canada (PPIC). First Edition. Printed by Oxford Graphic Printer, $150 \mathrm{pp}$.

Gardner FP, Pearce RB, \& Mitchell RL. 1991. Penerjemah Herawati susilo, Fisiologi Tanaman Budi daya, Jakarta : Universitas Indonesia Press.

Hanafiah, K. A. 2012. Dasar - Dasar Ilmu Tanah. Jakarta : Raja Grafindo Persada.

Hardjowigeno, S. 1993. Klasifikasi Tanah dan Pedogenesis. Jakarta : Akamedia Resindo.

Horwitz, William (Ed.). 2000. Official Methods of Analysis of AOAC International. 17th edition, Volume I, Agricultural Chemicals, Contaminants, Drugs. AOAC International, Maryland USA.

Hudori. 2007. Pemanfaatan Urine Manusia Sebagai Pupuk Pada Tanaman Tomat. Jurnal Teknik Lingkungan Universitas Islam Indonesia.

Indriani, Hety Yovita. 2011. Pembuatan Pupuk Kilat. Jakarta : Penerbit Penebar Swadaya.

Kinasti, Rr. Mekar Ageng., Lestari, Endah., Mayasari, Devita. 2018. Potensi Pemanfaatan Limbah Pembakaran Batu Bara (Bottom Ash) Pada PLTU Sebagai Media Tanam Dalam Upaya Mengurangi Pencemaran Lingkungan. Jurnal Kilat. Vol. 7 No. 1.

Khoirul Huda, Muhammad. 2013. Pembuatan Pupuk Organik Dari Urin Sapi Dengan Aditif Tetes Tebu (Molasses) Metode Fermentasi. Skripsi. Fakultas Matematika Dan Ilmu Pengetahuan Alam Universitas Negri Semarang.

Page, A.L., R.H. Miller, and D.R. Keeney (Eds.). 1982. Methods of Soil Analysis, Part 2- Chemical and microbiological properties, 2nd Edition. American Society of Agronomy, Madison, Wisconsin.

Probowati Sulistyani., Napoleon, A., Nurul Aidil Fitri, Siti., Dkk. 2013. Pemanfaatan Urine Kerbau Menjadi Pupuk Dan Pestisida Organik Cair Di Desa Sejaro Sakti Kecamatan Insralaya Kabupaten Ogan Ilir. Jurnal Pengabdian Masyarakat. Fakultas Pertanian Universitas Sriwijaya.

Rosmarkam, A \& Yuwono, NA, 2012, Ilmu Kesuburan Tanah, Kanisius. Yogyakarta.

Rina. 2015. Manfaat Unsur N, $\mathrm{P}$, dan K Bagi Tanaman.Tersedia di : http://kaltim.litbang.pertanian.go.id/ind/index.php?option=com content\&vi ew $=$ article \&id=707\&Itemid $=59$. (22 Februari 2020)

Sumarni., Rosliani, N., Duriat, A.S. 2010. Penelolaan Fisik, Kimia, dan Biologi Tanah untuk Meningkatkan Kesuburan Lahan dan Hasil Cabai Merah. Jurnal. Vol. 2 No. 20.

Sutedjo. 1996. Mikrobiologi Tanah. Jakarta : Trinika Cipta Jakarta. 